such as fibrinogen, are improved by exercise. ${ }^{17}$ Apart from the environmental benefits of cycling, there may be good grounds for encouraging a modal shift to the bicycle both as a means of transport and as part of any CHD prevention programme. On the other hand, these findings were made in a hilly area where cycling entails considerable effort and the benefits might not be as dramatic in flatter parts of the country. More data are required about the cardiovascular pathology of those who exercise regularly.

I am greatly indebted to $\mathrm{Mr} \mathrm{C}$ Dorries and $\mathrm{Mr} \mathrm{S}$ Hooper for permission to gather these data and to their respective staffs fo their considerable assistance. The older records were studied in the Sheffield Archives with the help of Mrs M Turner. I wish to thank the pathologists of South Yorkshire who allowed me to use the data from their reports and Mrs L A Norcliffe for secretarial assistance.

1 Morris JN, Heady JA, Raffle PAB, et al. Coronary heart disease and physical activity of work. Lancet 1953;ii:10537,1111-20.

2 Paffenbarger RS, Hyde RT, Jung DL, Wing AL. Epidemiology of exercise and coronary heart disease. Clin Sports Med 1984;3:297-318.

3 Robertson HK. Heart disease in lifelong cyclists. BMf $1975 ; 2: 1635-6$.
4 Morris JN, Clayton DG, Everitt MG, et al. Exercise in leisure time: coronary attack and death rates. $\mathrm{Br} \mathrm{Heart} f$ 1990;63:325-34

5 Vollmer-Larsen A, Vollmer-Larsen B, Kelbaek H, Godtfredson J. The veteran athlete: an echocardiographic comparison of veteran cyclists, former cyclists and non-athletic son of veteran cyclists, former cyclists and subjects Acta Physiol Scand 1989;135:393-8.

6 Shapiro LM. Physiological left ventricular hypertrophy. $B$ Heart $\mathcal{F} 1984 ; 52: 130-5$

7 Fagard R, Aubert A, Staessen J, Eynde EV, Vanhees L Amery A. Cardiac structure and function in cyclists and runners: a comparative echocardiographic study. Br Heart $\mathcal{f}$ 1984; 52:124-9.

8 Bekaert I, Pannier JL, van de Weghe C, et al. Non-invasive evaluation of cardiac function in professional cyclists. $B$ Heart $\mathcal{F} 1981 ; 45: 213-18$

9 Kennedy A. The pattern of injury in fatal pedal cycle accidents and the possible benefits of cycle helmets. $\mathrm{Br}$ Sports Med 1996;30:130-3.

10 Morris N, Crawford D. Coronary heart disease and physical activity of work: evidence of a national necropsy survey. BMF 1958;2:1485-96.

11 Mann JM, Davies MJ. Assessment of the severity coronary heart disease at postmortem examination. Are the measheart disease at postmortem examination. Are

12 Paffenbarger RS, Hale WE, Brand RJ, Hyde RT. Workenergy level, personal characteristics and fatal heart attack energy level, personal characteristics and fatal heart attack:

13 Wesslen L, Pahlson C, Lindquist $\mathrm{O}$, et al. An increase in sudden unexpected cardiac deaths among young Swedish orienteers during 1979-1992. Eur Heart f 1996;17:90210.

14 Lynch P. Soldiers, sport and sudden death. Lance 1980;i:1235-7.

5 Casperson CJ. Physical activity and coronary heart disease. Physician and Sports Medicine 1987;15:43-4.

16 Hendricksen IJM. The effect of commuter cycling on physical performance and on coronary heart disease risk factors. (Thesis). Amsterdam: University of Amsterdam, 1996.

17 Thompson WD, Smith EB. Atherosclerosis and the coagulation system. F Pathol 1989;159:97-106.

\section{Olympic freak show?}

Preparation of top level athletes entails intensive manipulation of their physiology and psychology. This is done mainly through controlling their lifestyle and diet, partly because of arbitrary limits set on the range of drugs that may be used to achieve the desired changes. I have argued ${ }^{1}$ that biotechnology, including genetic engineering, is opening new possibilities for producing athletic champions. Should we use these new means?

No, of course not, says the knee jerk reaction. I am not quite so sure. Sport, we are told, is a "good thing". Well, yes, people should take some exercise, and maybe it's even ok to encourage them to gang together in teams to slaughter rival teams. No doubt there was a time when sports champions were rounded people, mens sana in corpore sano, who trained a bit, ran their race, then got on with the other things in their lives. But not now. Becoming a top class athlete is a full time commitment and requires the services of dedicated teams of physiologists and psychologists. And if these turn out insufficient, maybe the pharmacologist can help. The combination of big money, national prestige, and prima donna status for the champion are irreversibly separating top level sport from any ideals. Each year the gap widens. Increasingly, world championships will be the province of one dimensional dehumanised products of a ruthless people engineering industry.
Professional telly sport has none of the virtues of participative amateur sport-it enriches a few, destroys a few, and turns millions into couch potatoes. We would be better off without it. But there is no hope of stopping its corrosive influence by laws or regulations. Only education can defeat it. As with antismoking campaigns, the aim must be to stop the practitioners being seen as role models. This is where cloning, genetic engineering, and the rest can help. Give the drug designers and genetic engineers free rein and they will turn professional sport into a freak show. Remember the East German athletes of the 1970 s - didn't they have a decidedly factory farmed look to them? Would you want your child to have been one of them? We can build on that first flicker of revulsion. The sacrifice of a few unfortunates-and it will be a few because of the cost-might be a modest price to pay for returning the rest of us to a state where sport is played by real people for fun.

ANDREW P READ

Professor of Human Genetics University of Manchester Department of Medical Genetics St Mary's Hospital Manchester M13 OfH

1 Read AP. Cloning for gold. Br $\mathcal{F}$ Sports Med 1997;31: 174. 